\title{
Perspective \\ Geo-engineering, Governance, and Social-Ecological Systems: Critical Issues and Joint Research Needs
}

Victor Galaz $^{1}$

\begin{abstract}
The debate about the possibilities to engineer the Earth's climate has changed drastically in the last years. Suggestions of large-scale technological interventions to combat climate change that a decade ago would have been discarded as science fiction are slowly moving into the center of international climate change discussions, research, and politics. In this article, I elaborate three joint key challenges to geo-engineering research from a resilience perspective, with a special emphasis on governance issues. First, I discuss the need to understand geo-engineering proposals from a "planetary boundaries" perspective. Second, I elaborate why the notion of Earth stewardship and geo-engineering are not necessarily in conflict, but instead could be viewed as complementary approaches. Last, I discuss the critical need to explore an institutional setting that is strong enough to weed out geo-engineering proposals that carry considerable ecological risk, but still allow for novelty, fail-safe experimentation, and continuous learning. These issues are critical for our understanding of how to effectively govern global environmental risks, complex systems, and emerging technologies in the Anthropocene.
\end{abstract}

Key Words: Earth stewardship, geo-engineering, global environmental governance, innovation, planetary boundaries, resilience thinking

\section{INTRODUCTION}

Human attempts to modify the climate are not new at all. On the contrary, history provides us with a number of examples of weather modification schemes, as well as larger scale suggestions on how to rework global scale climate dynamics (Fleming 2010). The debate about the possibilities to engineer Earth has however, changed drastically in the last years. Suggestions of large-scale technological interventions to combat climate change that a decade ago would have been discarded as science fiction are slowly moving toward the center of international climate change discussions, science, and politics.

A number of recent events are critical illustrations of this development. One of them is the joint inquiry on geoengineering carried out by the Science and Technology committees of the U.S. House of Representatives and the U. K. House of Commons (House of Commons 2010). The second is the recent initiative by the United Nations Intergovernmental Panel on Climate Change (IPCC) to include an assessment of geo-engineering technologies in its future fifth Assessment Reports (AR5, see www.ipcc.ch/pdf/ ar5/ar5-outline-compilation.pdf). A third illustration is the 2010 decision by the parties of the Convention on Biological Diversity (CBD), to create norms around geo-engineering activities, including experimentation and deployment. The decision (CBD 2010:5) "invites" governments "in the absence of science based, global, transparent and effective control and regulatory mechanisms for geo-engineering [...], that no climate-related geo-engineering activities that may affect biodiversity take place, until there is an adequate scientific basis on which to justify such activities and appropriate consideration of the associated risks, [...], with the exception of small scale scientific research studies that would be conducted in a controlled setting [...]." The legal practical implications of this decision are currently being elaborated by the CBD and its associated experts.

What is the role of resilience thinking in this emerging discussion? This might seem like an uncalled-for question, considering that geo-engineering approaches, e.g., the injection of stratospheric aerosols, and ecosystem-based solutions, e.g., carbon sequestration by terrestrial ecosystems, at a first glance might seem to differ considerably.

However, there are also some important parallels and issues of joint interest for the two communities. In this paper I identify these issues and briefly discuss in what ways resilience thinking (Folke et al. 2010) could contribute to this debate. The synthesis here is far from a complete analysis, but should instead be viewed as a think-piece intended to stimulate debate and further discussions.

The structure of the paper is the following. The first section summarizes briefly a range of technologies that have been denoted as "geo-engineering," and presents some important definitional tensions. The second section is divided in three parts, and identifies three key issues that should be of special interest from a resilience perspective: geo-engineering and planetary boundaries, Earth stewardship, and socialecological innovation, respectively.

\section{DEFINING GEO-ENGINEERING TECHNOLOGIES}

Defining "geo-engineering" and its associated technologies is far from a simple task. In fact, several definitions with different 
emphasis can be found in the literature (e.g., Royal Society 2009, United States House of Representatives Committee on Science and Technology 2009, U.S. Government Accountability Office 2010, Bipartisan Policy Center 2011). I define geo-engineering as intentional, technological largescale interventions in the climate system to mitigate the impacts of anthropogenic climate change.

It should be noted that this definition includes a suite of geoengineering proposals that differ considerably both in terms of the scale of experimentation, to deployment. For example, it includes both (1) solar radiation management techniques such as the deployment of stratospheric aerosols or whitening clouds in the lower atmosphere; as well as (2) carbon dioxide removal proposals such as ocean iron fertilization, carbon capture and storage, afforestation and reforestation, and the enhancing of soil carbon (for a more elaborate presentation, see Royal Society 2009, GAO 2011).

Hence, it should be noted that current discussions of geoengineering not only include technologies that intend to counteract warming through the regulation of solar radiation, e.g., injection of stratospheric aerosols, cloud brightening, increases in surface albedo, but also a suite of proposals that build on ecosystem-based approaches such as bioenergy with carbon capture and storage (BECCS), long-term storage of charcoal in soils (biochar), and reforestation and afforestation.

The word "intentional" is important because the definition excludes several global environmental change phenomena that characterize the Anthropocene (Steffen et al. 2004). For example, even though the global modification of water vapor (Dessler et al. 2008) and particle emissions from power plants (Wild et al. 2007) have clear climate impacts, these phenomena are normally not considered as geo-engineering because they lack explicit intent to intervene in the climate system.

The definition is not perfect, but captures a suite of technologies and proposed interventions in the climate system either by removing carbon dioxide from the atmosphere, or by trying to regulate incoming solar radiation. As witnessed during the 2010 meeting of the parties of the Convention on Biological Diversity (CBD) in Nagoya, Japan, several critical definitional issues remain. One is whether carbon capture and storage technologies should be included in the definition of geo-engineering (Sugiyama and Sugiyama 2010). The second is related to whether large-scale afforestation and reforestation projects should be included. The key definitional challenge in this case is "scale," i.e., how large-scale must a reforestation/ afforestation project be to be defined as "geo-engineering"? National interests play a clear role in this ongoing definitional battle as experienced during the last CBD Conference of the Parties meeting in Nagoya 2010 (see Earth Negotiations Bulletin No. 9 [544] http://www.iisd.ca/download/pdf/enb09544e. pdf; Sugiyama and Sugiyama 2010 for details on the discussions).
Several reports and articles have already elaborated the opportunities and risks associated with the deployment of geoengineering technologies (Lenton and Vaughan 2009, Royal Society 2009, GAO 2011). However, there is still a need to elaborate additional issues with clear connection to resilience science and the study of social-ecological systems.

\section{CRITICAL ISSUES AND JOINT RESEARCH NEEDS}

\section{Geo-engineering and planetary boundaries}

Recent syntheses of geo-engineering proposals increasingly consider not only the potential, but also possible negative environmental side effects of their deployment (e.g., Royal Society 2009, GAO 2011, Russell et al. 2012). Ranges of studies for example, explore the possible implications of injected aerosol particles on global precipitation patterns (Ricke et al. 2010); the ecosystem impacts of ocean fertilization (Wallace et al. 2010); and the possible increased land requirements for technologies such as "bio-char" (Fargione et al. 2008).

It should nevertheless be noted that none of the major geoengineering synthesis studies explore the possible implications of these technologies within a more general framework of "planetary boundaries" (Rockström et al. 2009a, $b$ ). More precisely, there currently exists no assessment of how geo-engineering technologies either individually or together, for example, combined deployment of stratospheric aerosols and ocean iron fertilization projects, could affect our ability to stay within the "safe operating space" identified by Rockström and colleagues $(2009 a, b)$. This is worrisome considering that practically all suggested geo-engineering technologies are likely to have direct or indirect impacts, via social-ecological interactions (e.g., Walker et al. 2009) on the identified "boundaries," such as freshwater use, biodiversity, and land use change.

One possible scenario is that the full-scale deployment of some geo-engineering technologies helps us stay within one boundary, i.e., climate change, but at the expense of several others, e.g., land use change. The possibility for short-term adaptation to undermine long-term social-ecological resilience is ever present (Adger et al. 2011), and geoengineering technologies cannot be assumed to be an exception.

However, at the same time it has been argued that the deployment of geo-engineering technologies instead might help us stay within several planetary boundaries such as climate, water, and biodiversity (e.g., Victor 2010, Lynas 2011). Large-scale reforestation and afforestation projects and improved management of agricultural land has the potential to offset global fossil fuel emissions and enhance additional ecosystem services (Trumper et al. 2009). The injection of stratospheric aerosols could rapidly decrease global mean 
temperatures and help protect species and ecosystems unable to adapt to rapid climate change (Secretariat of CBD 2009).

This sort of argument will become increasingly common as the chances of reaching the target to limit the global temperature rise to $2{ }^{\circ} \mathrm{C}$ above the average temperature before the industrial revolution become slimmer each year (e.g., Olivier et al. 2011). Needless to say, the uncertainties and trade-offs involved with intentionally trying to geo-engineer the climate are immense, and hard if not impossible to quantify.

A rough first attempt to at least analyze the full range of geoengineering technologies within the planetary boundaries framework would be more than helpful in a debate that has been so focused on climate change alone. This integration between planetary boundaries science and geo-engineering will be far from painless, however. The quantification of planetary boundaries remains preliminary and contested for several of the boundaries (see for example the seven invited responses in Nature's Climate Change blog, http://blogs.nature. com/climatefeedback/2009/09/planetary boundaries $1 . \mathrm{html}$ ). This uncertainty is particularly critical for possible interactions between planetary boundaries, a clear result of the complexity of the Earth system.

Similar uncertainties apply for the estimated potential and social-ecological risks involved with the experimentation and deployment of geo-engineering technologies. Vast uncertainties in all these research fields, i.e., planetary boundaries, their interactions, and the impacts of geo-engineering, will surely hinder effective cross-disciplinary scientific deliberation between planetary boundary researchers and geo-engineering scholars. However, this does not eliminate the need for more integrated assessment of geo-engineering proposals and their linkages to planetary boundaries and social-ecological resilience. Whether this integration will prove fruitful in the longer term, is worth further discussion.

\section{Geo-engineering governance and Earth stewardship}

An additional critical issue concerns global environmental governance. If geo-engineering technologies are to be experimented with, or deployed at larger scales, what are the major governance mechanisms, e.g., participation, legitimacy, transparency, and liability, that need to be in place? The academic debate on this issue is developing (Barrett 2008, Lin 2009, Blackstock and Long 2010, GAO 2010, Long and Winnickoff 2010, Victor 2010, Reynolds 2011). However, the emphasis is exclusively on creating proper governance mechanisms at the international level. This is a logical focus considering that the deployment of prominent geoengineering technologies such as the injection of stratospheric aerosols has clear international repercussions.

However, it should also be clear that both experimentation and deployment of all other geo-engineering technologies are likely to affect both local and regional scale ecosystems; systems that more often than not are being governed by natural resource users through local institutions, community management schemes, or transboundary partnerships such as those that underpin marine spatial planning.

For example, large-scale afforestation and reforestation projects, included by some in the geo-engineering tool-box set (e.g., Royal Society 2009), as well as land-based carbon dioxide removal, such as BECCS and charcoal production and storage, are far from being easy-to-implement technologies. On the contrary, conflicts over land use could arise unless explicitly addressed by national or local institutions. Disadvantaged users of ecosystems and their associated ecosystem services are also at constant risk of losing out in natural resource conflicts because they tend to have less of a voice in decision making at all levels, and may have less knowledge of regulations and policies to support their interests (Trumper et al. 2009).

The issue here is as much about physical resources as about cultural connections and worldviews associated with ecosystems and their management, often denoted as traditional ecological knowledge, such as forest taboo systems in Madagascar (Tengö et al. 2007), the cultural features of Balinese water temples (Lansing 2006), or the cultural embeddings of local ecological knowledge among Asian coastal communities (Kurien 1998). It would be a mistake to view this "cumulative body of knowledge, practice, and belief" (Berkes et al. 2000:1252) as irrelevant for geoengineering governance discussions. The reason is not only functional, because this knowledge has proven to be essential for adaptive ecosystem management (Berkes et al. 2000, Berkes et al. 2003, Folke et al. 2005). Its role is also embedded in several international agreements such as the Convention on Biological Diversity (see Mauro and Hardison 2000).

Whether a similar argument could be made for marine based geo-engineering interventions, such as marine based cloud brightening, ocean fertilization with iron or urea, and ocean $\mathrm{CO}_{2}$ storage, is less straightforward. Field experimentation with ocean fertilization as an example, is likely to have impacts on marine ecosystems depending on physical and biological conditions, some of which could be "far removed in space and time" (Wallace et al. 2010:1, see also Glibert et al. 2008, Russell et al. 2012).

Important work on this matter is assumed under the London Protocol and London Convention, but it is currently unclear how either experimentation or the deployment of these technologies would include the participation of a wide set of marine governance initiatives beyond nation states. These include various types of comanagement schemes, ranging from local coastal community-based management systems, to transboundary ocean governance initiatives such as the multinational Coral Triangle Initiative. These nested governance structures of which nation states are only one of many actors, have been proven to play a fundamental role in what has been denoted "scale-matching": that is, the ability of 
marine governance institutions to maximize ecological input; ensure the flow of ecological information between institutional levels; and internalize costs and benefits (Costanza et al. 1998). However, these ecosystem-based governance modes are consistently overlooked in current debates on geo-engineering governance.

A critical question therefore seems to be how future international institutional frameworks for geo-engineering experiments and deployment effectively can (1) engage with local ecosystem and cross-national comanagement arrangements; (2) build on local ecological knowledge that has evolved during considerable time frames through comanagement arrangements and processes of social learning; and (3) avoid undermining the effectiveness of mentioned nested ecosystem governance structures by imposing top-down regulations with poor understanding of local social-ecological contexts (Ostrom 2007).

These issues imply an approach to governance that is very different from current attempts to combine discussions on international institutions with studies of public perceptions of geo-engineering technologies (NERC 2010, Parkhill and Pidgeon 2011, Poumadère et al. 2011). It is different because it acknowledges the key role played by communities and polycentric arrangements in shaping change and surprise in social-ecological systems.

\section{Geo-engineering field experiments and Earth stewardship}

An emerging literature on "Earth stewardship" (Chapin et al. 2010, 2011) that provides models for collaboration between earth system science, ecological science, and local ecological knowledge, will prove essential in this context. It has been argued that geo-engineering and ecosystem stewardship are conflicting approaches because the former deal with "symptom treatment" rather than the reduction of anthropogenic pressures on the planet (Steffen et al. 2011:752).

However, this argument ignores the possibility to bring together Earth stewards with geo-engineering researchers to explore the prospects of conducting local to regional fail-safe experiments, that is, "creative experiments that cover scales and that can fail safely as new possibilities are created and tested" (Holling 2004). Earth stewards could play a key role in various phases of geo-engineering research, ranging from theory and modeling, to technology development, and subscale field-testing. Again, whether this is at all possible depends very much on the particular geo-engineering technique of interest, how the process of experimentation is designed, on what scale, and its precise location. Scaling up these experiments toward global scale would obviously pose difficult governance challenges, as has been discussed for geoengineering technologies in general.

Two issues will prove critical. One is to secure that geoengineering experiments explore technologies that not only address climate stresses, but could also bring multiple socialecological benefits to communities. This is especially the case for ecosystem-based carbon removal geo-engineering approaches, such as afforestation and reforestation, bioenergy with carbon capture and storage, and long-term storage of charcoal in soils. However, this could potentially also be relevant for proposals such as modifications of surface albedo through changes in land use, ocean fertilization, or enhanced ocean alkalinity ("liming the oceans") because they have direct impacts on local and regional ecosystem dynamics. However, it should be stressed that the ecosystem impacts are heavily dependent on both the form and location for deployment (see Russell et al. 2012 for details). This raises questions about how to design participation processes that are inclusive enough to create joint expectations of benefits and costs (Mauro and Hardison 2000), but flexible enough to handle unexpected social or ecological impacts (e.g., Barreteau et al. 2010).

Second, participatory and comanagement processes always play out within an institutional context. Hence, the creation of institutional mechanisms at the national or international level that support consultation, the disclosure of information, provide ombudsmen functions, and endorse integrated assessments of social-ecological dimensions will provide a critical underpinning for participatory processes. Examples of these so-called "safeguard" policies are currently being elaborated and evaluated by the World Bank for development projects (Dani et al. 2011), as well in the CBD Akwé: Kon Voluntary Guidelines for the Conduct of Cultural, Environmental and Social Impact Assessment (Secretariat of CBD 2004), and could provide a good basis for discussions on how to support future dialogues between Earth stewards and geo-engineering researchers.

\section{Framing or regulating innovation?}

Renewal and novelty have always been central elements of resilience thinking (Folke et al. 2010). Innovation as a research topic is also gaining prominence because it relates to socialecological systems, planetary boundaries, and ecosystem services (Homer-Dixon 2000, Biggs et al. 2010, Olsson and Galaz 2011, Westley et al. 2011). Westley and colleagues (2011) note that although the innovative capacity of human societies has brought us considerable benefits, there is also an urgent need to frame these within the boundaries of the biosphere. More precisely, "it implies weaning ourselves from this addiction to innovation for its own sake, or at the very least finding the institutional frameworks to stimulate the kinds of innovation that solve rather than augment our environmental challenges" (Westley et al. 2011:4-5).

However, creating a proper "institutional framework" to direct innovation is far from a simple task. Innovation dynamics are inherently complex, and ill-designed innovation policies can easily lead to perverse incentives and unwanted outcomes (Avelino 2009). This often leads to calls for adaptive modes of innovation governance or reflexive modes of law (as suggested by Westley et al. 2011) because it might allow for 
careful adaptive steering of bottom-up experimentation in socalled "niches" (Loorbach 2010).

However, geo-engineering technologies pose fundamentally different steering challenges compared to the innovations described by Biggs et al. (2010), Olsson and Galaz (2011), and Westley et al. (2011), for at least two reasons. The first is biogeophysical, as the experimentation or deployment of many of the proposed technologies, ranging from the injection of stratospheric aerosols, to iron fertilization, and cloud seeding, could if deployed on large scales, have unexpected negative ecosystem side-effects. The second reason is related to the socio-political contentious nature of geo-engineering. Geo-engineering experiments like the British Stratospheric Particle Injection for Climate Engineering (SPICE); experimentation with iron ocean fertilization such as the Indian-German LOHAFEX experiment in 2009 (Naqvi and Smetacek 2011); and carbon storage in several parts of the world have all induced intense opposition from among others, civil society organizations and in the case of carbon storage, also from local communities, sometimes denoted as "Not Under My Backyard" (NUMBY). Even though carbon capture and storage is normally not viewed as geo-engineering, public opposition was explicitly concerned with leakage in carbon storage. Proposed ambient air capture or "artificial trees" would nevertheless require the same sort of storage, and hence are likely to raise similar NUMBY debates.

This, I believe, forces innovation scholars in the resilience community to seriously explore not only the adaptive "framing" of bottom-up innovations such as small-scale water harvesting technologies, innovative economic ecosystem payment schemes, or new ecosystem management approaches (see Olsson and Galaz 2011), but also considerably stronger forms of regulation of potentially high-risk, but also potentially high-benefit, proposals such as solar radiation management technologies.

One particularly critical question seems to be how to create an institutional setting that is strong enough to weed out geoengineering proposals that carry considerable ecological risk, but still allow for novelty, fail-safe experimentation (Holling 2004), and continuous and ecological literate learning. The diffusion dynamics of innovation, and their potential positive and negative externalities, highlight the need for overarching governance principles for resolving conflicts and facilitating coordination in institutionally fragmented settings (Galaz et al. 2012).

This issue seems to be most critical for solar radiation management, especially the injection of stratospheric aerosols, where fail-safe large-scale field-testing experimentation might be impossible. At the same time, potential risks with new technologies can only be proven through actual research and development, an argument often denoted as the "control dilemma" (Royal Society 2009:37, Bracmort et al. 2011:4).
Insights from initiatives such as the Solar Radiation Management Governance Initiative (www.srmgi.org/) will prove critical.

In sum, whether the regulation of such a wide diversity of techniques is most effectively assumed through multilateral treaty making, by polycentric self-regulating approaches, or by soft law approaches is a much-debated issue within the geoengineering research community (e.g., Victor 2010, Reynolds 2011). Resilience scholars could make a valuable contribution to this debate by bringing in an understanding of the need to maintain diversity as a portfolio of options, as well as the role of innovation in building social-ecological resilience.

It should be noted that this is an issue that goes beyond geoengineering technologies. Technological change is pushing humanity into not only the Anthropocene, but also well beyond geo-engineering technologies. New sectors such as information technology, biotechnology, artificial intelligence, synthetic biology, and robotics hold great promise for human well-being, but also possible risks. In addition, truly disruptive technologies are often the result of unexpected recombinations of existing technologies (Arthur 2009, Kelly 2010).

These recombinations are notoriously difficult to predict (Kelly 2010) but risk having important ecosystem impacts. Geo-engineering technologies are not an exception but include proposals to inject nano-particles in the stratosphere (Keith 2010), as well as suggestions to design biotechnologically modified crops to enhance their albedo properties (Rigwell et al. 2009). Brian Arthur's observation that technology matures, diversifies, and scales at an accelerating pace (Arthur 2009) is not only a reason for optimism, but also for seriously exploring international and national institutional frameworks able to maintain innovation within the boundaries of the planet.

\section{CONCLUDING COMMENTS}

Can we geo-engineer Earth in ways that allow humanity to stay within critical planetary boundaries? What are the best ways to acknowledge the fundamental role played by Earth stewards in current international attempts to govern geoengineering proposals and technologies? And how do we stay ahead of novel recombinations of technologies that could help us steer away from devastating nonlinear environmental change, but that could also create novel, large-scale ecological risks? These are all questions that emerge as the result of an increasingly intense debate about the opportunities and risks involved with geo-engineering, large-scale technological interventions in the climate system.

Table 1 summarizes several prominent geo-engineering approaches, including key issues that relate to current work on social-ecological systems and their governance.

Recognizing that humanity has moved into the Anthropocene has important repercussions, not only because it forces us to 
Table 1. A selection of geo-engineering proposals, and key issues from a resilience perspective.

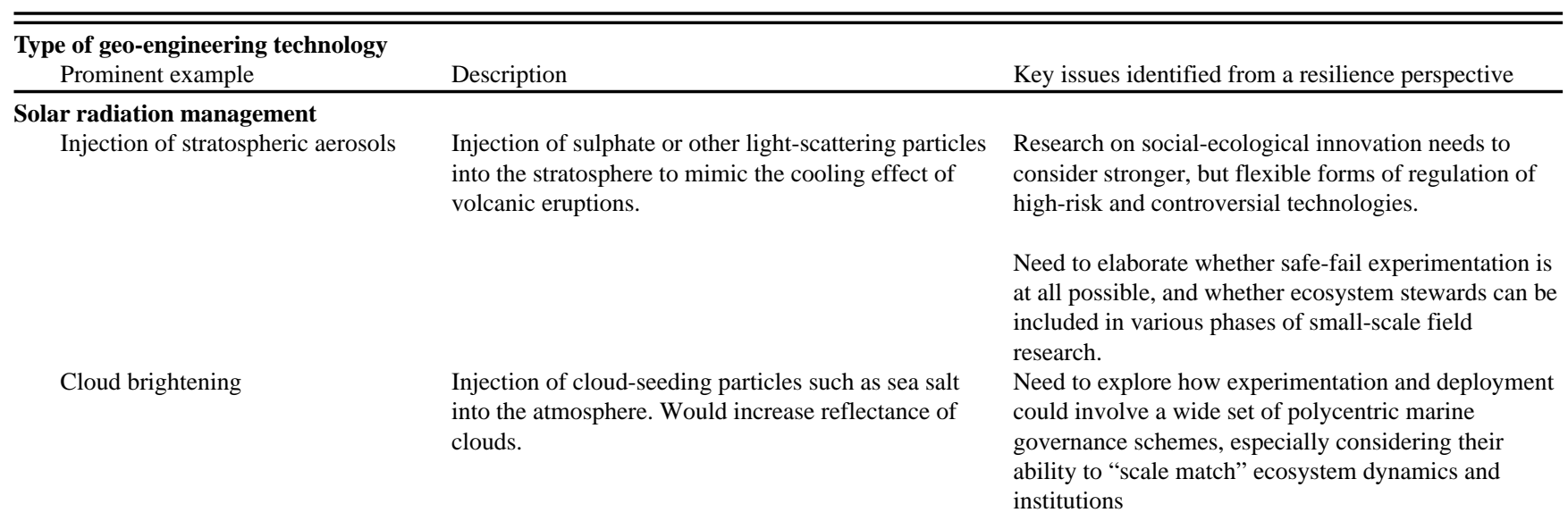

Land-based carbon dioxide removal (CDR) Afforestation and land use Strategies based around the protection and management of key ecosystems to enhance the drawdown of $\mathrm{CO}_{2}$ from the atmosphere.

Need to explore how possible conflicts over land use can be addressed by local ecosystem management institutions, including cultural considerations.

Need to elaborate whether field experiments could be designed in collaboration with Earth stewards in ways that not only secure transparency and participation, but also bring multiple social-ecological benefits to communities.

Biomass and biomass-related methods

Atmospheric $\mathrm{CO}_{2}$ scrubbers, "air capture," "artificial trees"

Ocean-based carbon dioxide removal Ocean fertilization

Ocean upwelling or downwelling

Alkalinity enhancement
Growing terrestrial vegetation removes large quantities of carbon from the atmosphere through photosynthesis. Resulting $\mathrm{CO}_{2}$ can be sequestered in geological formations (BECCS), or sequestered as organic material by e.g., burying charcoal ('biochar').

Industrial process that captures $\mathrm{CO}_{2}$ from ambient air producing a pure $\mathrm{CO}_{2}$ stream for use or disposal.

The addition of nutrients such as nitrogen or iron into the oceans to enhance algal blooms. Resulting photosynthetic activity has been suggested to increase storage of carbon from the atmosphere into the deep ocean.

The rate at which atmospheric carbon is transferred to the deep sea, may be enhanced by increasing the supply of nutrients by the upwelling or overturning circulation of the ocean.

Carbon dioxide is naturally removed from the atmosphere over many thousands of years by processes involving the weathering (dissolution) of carbonate and silicate rocks. Proposals aim to artificially increase the rates of these processes by introducing the dissolution products of alkaline minerals into the oceans.
Unclear implications, highly dependent on projected land requirement and location.

Possible similar needs as for land-based CDR, i.e., to elaborate the prospect of experiments in collaboration with marine governance initiatives with an emphasis on multiple social-ecological benefits.

Unclear implications, highly dependent on projected location.

Possibly similar needs as for land-based CDR, i.e., to elaborate the prospect of experiments in collaboration with marine governance initiatives with an emphasis on multiple social-ecological benefits.

Comment: Columns 1-3 build on Royal Society (2009). Please note that the selection of technologies is not complete, but rather a selection of prominent examples. Details of fourth column can be found in the article.

consider resilience at the planetary scale (Rockström et al. $2009 a, b)$, but also because it forces us to discuss whether it is desirable to shift from unintentional modifications and experimentation with the Earth system to an approach where we intentionally try to modify the climate and associated biogeophysical systems to humanity's benefit.
This potential shift in how we approach Earth system governance and stewardship involves conflictive trade-offs, and managing risks and uncertainty at unprecedented scales. In addition, the ethical and socio-political characteristics of the issue seriously challenge institutional capacities at all scales, ranging from global environmental institutions to 
community-based management systems. The resilience community could contribute in fundamental ways to this controversial and critical emerging debate. This article should be viewed as a mere start.

Responses to this article can be read online at: http://www.ecologyandsociety.org/voll7/iss 1/art24/ responses/

\section{Acknowledgments:}

This paper has benefited considerably from discussions with colleagues such as Fredrik Moberg, Frances Westley, Maria Schultz, Stuart Chapin, Jason Blackstock, and Per Olsson. I would also like to thank the two anonymous reviewers for excellent comments on previous drafts, as well as participants of the Convention on Biological Diversity Liaison Expert group on geo-engineering and biodiversity, especially Andrew Parker, Chris Evans, Ralph Bodle, Georgina Mace, and James Fleming. This work has been funded by the Futura Foundation, and SwedBio. The perspectives presented here are however, my own.

\section{LITERATURE CITED}

Adger, W. N., K. Brown, D. R. Nelson, F. Berkes, H. Eakin, C. Folke, K. Galvin, L. Gunderson, M. Goulden, K. O'Brien, J. Ruitenbeek, and E. L. Tompkins. 2011. Resilience implications of policy responses to climate change. WIREs Climate Change 2:757-766. http://dx.doi.org/10.1002/wcc.133

Arthur, W. B. 2009. The nature of technology: what it is and how it evolves. Free Press, New York, New York, USA.

Avelino, F. 2009. Empowerment and the challenge of applying transition management to ongoing projects. Policy Sciences 42(4):369-390. http://dx.doi.org/10.1007/s11077-009-9102-6

Barrett, S. 2008. The incredible economics of geoengineering. Environmental and Resource Economics 39:45-54. http://dx.d oi.org/10.1007/s10640-007-9174-8

Barreteau, O., P. W. G. Bots, and K. A. Daniell. 2010. A framework for clarifying "participation" in participatory research to prevent its rejection for the wrong reasons. Ecology and Society 15(2): 1. [online] URL: http://www.ecologyands ociety.org/vol15/iss2/art1/

Berkes, F., J. Colding, and C. Folke. 2000. Rediscovery of traditional ecological knowledge as adaptive management. Ecological Applications 10(5):1251-1262. http://dx.doi.org/1 0.1890/1051-0761(2000)010[1251:ROTEKA]2.0.CO;2
Berkes. F., J. Colding, and C. Folke. 2003. Navigating socialecological systems: building resilience for complexity and change. Cambridge University Press, Cambridge, UK.

Biggs, R., F. R. Westley, and S. R. Carpenter. 2010. Navigating the back loop: fostering social innovation and transformation in ecosystem management. Ecology and Society 15(2): 9. [online] URL: http://www.ecologyandsociety. org/vol15/iss2/art9/

Bipartisan Policy Center. 2011. Geoengineering: a national strategic plan for research on the potential effectiveness, feasibility, and consequences of climate remediation technologies. Bipartisan Policy Center, Washington, D.C., USA.

Blackstock, J. J., and J. C. S. Long. 2010. The politics of geoengineering. Science 327(5965):527. http://dx.doi.org/10. $\underline{1126 / \text { science. } 1183877}$

Bracmort, K., R. K. Lattanzio, and E. C. Barbour. 2001. Geoengineering: governance and technology policy. Congressional Research Service (R41371), Washington, D. C., USA.

Chapin, F. S., III, S. R. Carpenter, G. P. Kofinas, C. Folke, N. Abel, W. C. Clark, P. Olsson, D. M. Stafford Smith, B. H. Walker, O. R. Young, F. Berkes, R. Biggs, J. M. Grove, R. L. Naylor, E. Pinkerton, W. Steffen, and F. J. Swanson. 2010. Ecosystem stewardship: sustainability strategies for a rapidly changing planet. Trends in Ecology \& Evolution 25:241-249. http://dx.doi.org/10.1016/j.tree.2009.10.008

Chapin, F. S., III, M. E. Power, S. T. A. Pickett, A. Freitag, J. A. Reynolds, R. B. Jackson, D. M. Lodge, C. Duke, S. L. Collins, A. G. Power, and A. Bartuska. 2011. Earth stewardship: science for action to sustain the human-earth system. Ecosphere 2(8):art89. http://dx.doi.org/10.1890/ES11 $\underline{-00166.1}$

Convention on Biological Diversity (CBD). 2010. Decision adopted by the Conference of the Parties to the Convention on Biological Diversity at its tenth meeting, UNEP/CBD/COP/ $D E C / X / 33$. United Nations Environment Programme, CBD, Montreal, Quebec, Canada. [online] URL: http://www.cbd.int/ climate/doc/cop-10-dec-33-en.pdf

Costanza, R., F. Andrade, P. Antunes, M. van den Belt, D. Boersma, D. F. Boesch, F. Catarino, S. Hanna, K. Limburg, B. Low, M. Molitor, J. G. Pereira, S. Rayner, R. Santos, J. Wilson, and M. Young. 1998. Principles for sustainable governance of the oceans. Science 281(5374):198-9. http://dx .doi.org/10.1126/science.281.5374.198

Dani, A., A. Freeman, and V. Thomas. 2011. Evaluative directions for the World Bank Group's safeguards and sustainability policies. Evaluation Brief 15. World Bank, 
Washington D.C., USA. [online] URL: http://ieg.worldbankg roup.org/content/dam/ieg/EvalBriefs/eb safeguards.pdf

Dessler, A. E., Z. Zhang, and P. Yang. 2008. Water-vapor climate feedback inferred from climate fluctuations, 2003-2008. Geophysical Research Letters 35:L20704. http:// dx.doi.org/10.1029/2008GL035333

Fargione, J., J. Hill, D. Tilman, S. Polasky, and P. Hawthorne. 2008. Land clearing and the biofuel carbon debt. Science 319 (5867):1235-1238. http://dx.doi.org/10.1126/science.1152747

Fleming, J. R. 2010. Fixing the sky: the checkered history of weather and climate control. Columbia University Press, New York, New York, USA.

Folke, C., S. R. Carpenter, B. Walker, M. Scheffer, T. Chapin, and J. Rockström. 2010. Resilience thinking: integrating resilience, adaptability, and transformability. Ecology and Society 15(4): 20. [online] URL: http://www.ecologyandsociety. org/vol15/iss4/art20/

Folke, C., T. Hahn, P. Olsson, and J. Norberg. 2005. Adaptive governance of social-ecological systems. Annual Review of Environment and Resources 30:441-473. http://dx.doi.org/10 $.1146 /$ annurev.energy.30.050504.144511

Galaz, V., F. Biermann, B. Crona, D. Loorbach, C. Folke, P. Olsson, M. Nilsson, A. Persson, and G. Reischl. 2012. 'Planetary boundaries'-exploring the challenges for global environmental governance. Current Opinion in Environmental Sustainability 4:80-87. http://dx.doi.org/10.1016/j.cosust.201 2.01.006,

Glibert, P. M., R. Azanza, M. Burford, K. Furuya, E. Abal, A. Al-Azri, F. Al-Yamani, Per Andersenh, M. Andersoni, J. Beardallj, G. M. Bergk, L. Brandl, D. Bronkm, J. Brookesn, J. M. Burkholdero, A. Cembellap, W. P. Cochlanq, J. L. Collierr, Y. Colloss, R. Diazm, M. Doblint, T. Drennenu, S. Dyhrmani, Y. Fukuyov, M. Furnasw, J. Gallowayx, E. Granéliy, D. V. Haz, G. Hallegraeffaa, J. Harrisonab, P. J. Harrisonac, C. A. Heilad, K. Heimannae, R. Howarthaf, C. Jauzeins, A. A. Kanau, T. M. Kanaa, H. Kimag, R. Kudelaah, C. Legrandy, M. Mallinai, M. Mulhollandaj, S. Murrayak, J. O'Neila, G. Pitcheral, Y. Qiam, N. Rabalaisan, R. Raineao, S. Seitzingerap, P. S. Salomony, C. Solomonaq, D. K. Stoeckera, G. Usupar, J. Wilsonas, K. Yinc, M. Zhouat, and M. Zhu. 2008. Ocean urea fertilization for carbon credits poses high ecological risks. Marine Pollution Bulletin 56(6):1049-56. http://dx.doi.org/10.1016/j.marpolbul.2008.03.010

Government Accountability Office. 2010. Climate change: preliminary observations on geoengineering science, federal efforts, and governance issues. Report GAO-10-546T. GAO, Washington, D.C., USA.
Government Accountability Office. 2011. Climate engineering: technical status, future directions, and potential responses. Report GAO-11-71. GAO, Washington, D.C., USA.

Holling, C. S. 2004. From complex regions to complex worlds. Ecology and Society 9(1): 11. [online] URL: http://www.ecol ogyandsociety.org/vol9/iss1/art11

Homer-Dixon, T. 2000. The ingenuity gap. Knopf, New York, New York, USA.

House of Commons. 2010. The regulation of geoengineering - fifth report of session 2009-10. Report, together with formal minutes, oral and written evidence. House of Commons Science and Technology Committee, London, UK.

Keith, D. W. 2010. Photophoretic levitation of engineered aerosols for geoengineering. Proceedings of the National Academy of Sciences 107(38):16428-16431. http://dx.doi.org /10.1073/pnas.1009519107

Kelly, K. 2010. What technology wants. Penguin, New York, New York, USA.

Kurien, J. 1998. Traditional ecological knowledge and ecosystem sustainability: new meaning to Asian coastal proverbs. Ecological Applications 8(1):S2-S5. http://dx.doi.o $\mathrm{rg} / 10.2307 / 2641358$

Lansing, S. 2006. Perfect order - recognizing complexity in Bali. Princeton University Press, Princeton, New Jersey, USA.

Lenton, T. M., and N. E. Vaughan. 2009. The radiative forcing potential of different climate geoengineering options. Atmospheric Chemistry and Physics 9:5539-5561. http://dx.d oi.org/10.5194/acp-9-5539-2009

Lin, A. C. 2009. Geoengineering governance. Issues in Legal Scholarship 8(3):1-24. http://dx.doi.org/10.2202/1539-8323.1112

Long, J., and D. Winickoff. 2010. Geoengineering research: principles and process. Solutions 1(5):60-62.

Loorbach, D. 2010. Transition management for sustainable development: a prescriptive, complexity-based governance framework. Governance 23:161-183. http://dx.doi.org/10.1111/ j.1468-0491.2009.01471.x

Lynas, M. 2011. The God species: how the planet can survive the age of humans. Harper Collins, London, UK.

Mauro, F., and P. D. Hardison. 2000. Traditional knowledge of indigenous and local communities: international debate and policy initiatives. Ecological Applications 10(5):1263-1269. http://dx.doi.org/10.1890/1051-0761(2000)010[1263:TKOIAL] 2.0.CO;2 
Naqvi, S. W. A., and V. Smetacek. 2011. Ocean iron fertilization. Pages 197-206 in P. Jacquet, R. K. Pachauri, and L. Tubiana, editors. Oceans: the new frontier. TERI Press, New Delhi, India. [online] URL: http://drs.nio.org/drs/handle $\underline{12264 / 3885}$

National Environment Research Council (NERC). 2010. Experiment Earth? Report on a public dialogue on geoengineering. NERC, London, UK. [online] URL: http://w ww.nerc.ac.uk/about/consult/geoengineering-dialogue-final-report. pdf

Olivier, J. G. J., G. Janssens-Maenhout, J. A. H. W. Peters, and J. Wilson. 2011. Long-term trend in global CO2 emissions. 2011 report. PBL Netherlands Environmental Assessment Agency and European Commission's Joint Research Centre, The Hague, The Netherlands.

Olsson, P., and V. Galaz. 2011. Social-ecological innovation and transformation. In A. Nicholls, and A. Murdoch, editors. Social innovation: blurring sector boundaries and challenging institutional arrangements. Palgrave MacMillan, Basingstoke, UK.

Ostrom, E. 2007. A diagnostic approach for going beyond panaceas. Proceedings of the National Academy of Sciences 104(39):15181-15187. http://dx.doi.org/10.1073/pnas.0702288104

Parkhill, K., and N. Pidgeon. 2011. Public engagement on geoengineering research: a preliminary report on the SPICE deliberative workshops. Understanding Risk Group Working Paper 11-01. Cardiff University School of Psychology, Cardiff, UK.

Poumadère, M., R. Bertoldo, and J. Samadi. 2011. Public perceptions and governance of controversial technologies to tackle climate change: nuclear power, carbon capture and storage, wind, and geoengineering. WIREs Climate Change 2:712-727. http://dx.doi.org/10.1002/wcc.134

Reynolds, J. 2011. The regulation of climate engineering. Law, Innovation and Technology 3(1):113-136. http://dx.doi.org/10 $.5235 / 175799611796399821$

Ricke, K. L., M. G. Morgan, and M. R. Allen. 2010. Regional climate response to solar radiation management. Nature Geoscience 3:537-541. http://dx.doi.org/10.1038/ngeo915

Rigwell, A., J. S. Singarayer, A. M. Hetherington, and P. J. Valdes. 2009. Tackling regional climate change by leaf albedo bio-geoengineering. Current Biology 19(2):146-150. http://dx .doi.org/10.1016/j.cub.2008.12.025

Rockström, J., W. Steffen, K. Noone, Å. Persson, F. S. Chapin, III, E. F. Lambin, T. M. Lenton, M. Scheffer, C. Folke, H. J. Schellnhuber, B. Nykvist, C. A. de Wit, T. Hughes, S. van der Leeuw, H. Rodhe, S. Sörlin, P. K. Snyder, R. Costanza, U.
Svedin, M. Falkenmark, L. Karlberg, R. W. Corell, V. J. Fabry, J. Hansen, B. Walker, D. Liverman, K. Richardson, P. Crutzen, and J. A. Foley. 2009a. A safe operating space for humanity. Nature 461:472-475. http://dx.doi.org/10.1038/461472a

Rockström, J., W. Steffen, K. Noone, Å. Persson, F. S. Chapin, III, E. Lambin, T. M. Lenton, M. Scheffer, C. Folke, H. Schellnhuber, B. Nykvist, C. A. De Wit, T. Hughes, S. van der Leeuw, H. Rodhe, S. Sörlin, P. K. Snyder, R. Costanza, U. Svedin, M. Falkenmark, L. Karlberg, R. W. Corell, V. J. Fabry, J. Hansen, B. Walker, D. Liverman, K. Richardson, P. Crutzen, and J. Foley. 2009b. Planetary boundaries: exploring the safe operating space for humanity. Ecology and Society 14(2): 32. [online] URL: http://www.ecologyandsociety.org/v ol14/iss $2 / \operatorname{art} 32 /$

Royal Society. 2009. Geoengineering the climate: science, governance and uncertainty. RS Policy document 10/09. The Royal Society, London, UK.

Russell, L. M., P. J. Rasch, G. M. Mace, R. B. Jackson, J. Shepherd, P. Liss, M. Leinen, D. Schimel, N. E. Vaughan, A. C. Janetos, P. W. Boyd, R. J. Norby, K. Caldeira, J. Merikanto, P. Artaxo, J. Melillo, and M. Granger Morgan. 2012. Ecosystem impacts of geoengineering. AMBIO, in press.

Secretariat of the Convention on Biological Diversity. 2004. Akwé: Kon Guidelines. Secretariat of the Convention on Biological Diversity, Montreal, Quebec, Canada. [online] URL: http://www.cbd.int/doc/publications/akwe-brochure-en. pdf

Secretariat of the Convention on Biological Diversity. 2009. Connecting biodiversity and climate change mitigation and adaptation: report of the Second Ad Hoc Technical Expert Group on Biodiversity and Climate Change. Technical Series No.41. Secretariat of the Convention on Biological Diversity, Montreal, Quebec, Canada.

Steffen, W., A. Sanderson, P. D. Tyson, J. Jäger, P. A. Matson, B. Moore, III, F. Oldfield, K. Richardson, H. J. Schellnhuber, B. L. Turner, II, and R. J. Wasson. 2004. Global change and the Earth system: a planet under pressure. Springer Verlag, Berlin, Germany.

Steffen, W., Å. Persson, L. Deutsch, J. Zalasiewicz, M. Williams, K. Richardson, C. Crumley, P. Crutzen, C. Folke, L. Gordon, M. Molina, V. Ramanathan, J. Rockström, M. Scheffer, H. J. Schellnhuber, and U. Svedin. 2011. The anthropocene: from global change to planetary stewardship. Ambio 40(7):739-761. http://dx.doi.org/10.1007/s13280-011-0185$\underline{\mathrm{x}}$

Sugiyama, M., and T. Sugiyama. 2010. Interpretation of CBD COP10 decision on geoengineering. Socio-Economic Research Center Discussion Paper SERC10013. Central Research Institute of Electric Power Industry, Tokyo, Japan. 
[online] URL: https://docs.google.com/viewer?url=http\%3A\% 2F\%2Fwww.climatepolicy.jp\%2Fthesis\%2Fpdf\%2F10013dp. pdf

Tengö, M., K. Johansson, F. Rakotondrasoa, J. Lundberg, J.A. Andriamaherilala, J.-A. Rakotoarisoa, and T. Elmqvist. 2007. Taboos and forest governance: informal protection of hot spot dry forest in southern Madagascar. Ambio 36 (8):683-691. http://dx.doi.org/10.1579/0044-7447(2007)36[683: TAFGIP]2.0.CO;2

Trumper, K., M. Berzky, B. Dickson, G. van der Heijden, M. Jenkins, and P. Manning. 2009. The natural fix? The role of ecosystems in climate mitigation. UNEP rapid response assessment. United Nations Environment Programme, Cambridge, UK

United States House of Representatives Committee on Science and Technology. 2009. Engineering the climate: research needs and strategies for international coordination. Committee on Science and Technology, Washington, D.C., USA.

Victor, D. G. 2010. Global warming gridlock: creating more effective strategies for protecting the planet. Cambridge University Press, Cambridge, UK.

Wallace, D. W. R., C. S. Law, P. W. Boyd, Y. Collos, P. Croot, K. Denman, P. J. Lam, U. Riebesell, S. Takeda, and P. Williamson. 2010. Ocean fertilization: a scientific summary for policy makers. Intergovernmental Oceanographic Commission/UNESCO, Paris, France.

Walker, B., S. Barrett, S. Polasky, V. Galaz, C. Folke, G. Engström, F. Ackerman, K. Arrow, S. Carpenter, K. Chopra, G. Daily, P. Ehrlich, T. Hughes, N. Kautsky, S. Levin, K.-G. Mäler, J. Shogren, J. Vincent, T. Xepapadeas, and A. de Zeeuw. 2009. Looming global-scale failures and missing institutions. Science 325:1345-1346. http://dx.doi.org/10.1126/ science. 1175325

Westley, F., P. Olsson, C. Folke, T. Homer-Dixon, H. Vredenburg, D. Loorbach, J. Thompson, M. Nilsson, E. Lambin, J. Sendzimir, B. Banerjee, V. Galaz, and S. van der Leeuw. 2011. Tipping toward sustainability: emerging pathways of transformation. Ambio 40(7):762-780. http://dx.d oi.org/10.1007/s13280-011-0186-9

Wild, M., A. Ohmura, and K. Makowski. 2007. Impact of global dimming and brightening on global warming. Geophysical Research Letters 34:L04702. http://dx.doi.org/d oi:10.1029/2006GL028031 